\title{
Radium-226 in the Kuroshio Water Near Taiwan: Results From the KEEP and KEEP-MASS Programs
}

\author{
YU-CHIA CHUNG ${ }^{1}$, and HUNG-CHOU YIN ${ }^{1}$ \\ (Manuscript received 7 May 1994, in final form 20 December 1994)
}

ABSTRACT

This paper presents some initial results of the ${ }^{226} \mathrm{Ra}$ measurements on seawaters from the areas off northern Taiwan where the Kuroshio water encounters the East China Sea water and off eastern Taiwan within the Kuroshio current. Samples were collected from the sea surface and also in the water column during the KEEP-MASS cruise onboard the $R / V$ Vinogradov and three other cruises onboard the $R / V$ Ocean Researcher $I$.

Surface water ${ }^{226} \mathrm{Ra}$ varies somewhat randomly between 6.1 and 12.8 $\mathrm{dpm} / 100 \mathrm{~kg}$ in the study area with a slight tendency to increase northward along the Kuroshio path off eastern Taiwan. Similar but less random variations were observed by Nozaki in the northern East China Sea surface water.

The shallow water ${ }^{226} \mathrm{Ra}$ profiles in the shelf and upper slope areas show fairly uniform values at about $10 \mathrm{dpm} / 100 \mathrm{~kg}$. The intermediate and deep water profiles in the lower slope and deep basin off the east coast of Taiwan show a monotonous increase from south to north in the layer between the depths of $300 \mathrm{~m}$ and $1000 \mathrm{~m}$. The deep profiles at the south display a pronounced ${ }^{226} \mathrm{Ra}$ increase from about $12 \mathrm{dpm} / 100 \mathrm{~kg}$ at $1000 \mathrm{~m}$ to about 30 $\mathrm{dpm} / 100 \mathrm{~kg}$ at $2500 \mathrm{~m}$ and remain relatively constant below.

Although the northward ${ }^{226} \mathrm{Ra}$ increase in the intermediate depth along the Kuroshio is contradictory to the conventional notion predicting no significant change along the flow, it is nonetheless consistent with the hydrographic data which show clear changes from south to north.

Published ${ }^{210} \mathrm{~Pb}$ profiles in the study area also show significant changes both in shape and activity level. Comparisons between these ${ }^{210} \mathrm{~Pb}$ profiles with the ${ }^{226} \mathrm{Ra}$ profiles measured in adjacent areas in this study indicate that the ${ }^{210} \mathrm{~Pb}$ excess due to the atmospheric flux may penetrate down to about the depths of $300 \mathrm{~m}$ to $1000 \mathrm{~m}$. As the decay rate of the excess ${ }^{210} \mathrm{~Pb}$ is small compared to the atmospheric flux, the scavenging residence time for ${ }^{210} \mathrm{~Pb}$ is controlled mainly by the atmospheric flux and the inventory of excess ${ }^{210} \mathrm{~Pb}$. The ${ }^{210} \mathrm{~Pb}$ scavenging residence time calculated for the excess ${ }^{210} \mathrm{~Pb}$ based

${ }^{1}$ Institute of Marine Geology, National Sun Yat-Sen University, Kaohsiung, Taiwan, R.O.C. 
on a box model ranges from 2.3 to $8.8 \mathrm{yrs}$, which is proportional to the depth of the excess ${ }^{210} \mathrm{~Pb}$ penetration.

The ${ }^{210} \mathrm{~Pb} /{ }^{226} \mathrm{Ra}$ activity ratio is about 0.25 below the $1000 \mathrm{~m}$ depth in the area off northeastern Taiwan, giving a scavenging residence time of about 10 yrs for $\mathbf{P b}$. This value is quite comparable to that obtained from the bottom water in the deep open oceans.

\section{(Key words: ${ }^{226} \mathrm{Ra}$, Kuroshio, Hydrography, Excess ${ }^{210} \mathrm{~Pb}$, Box model, Scavenging residence time)}

\section{INTRODUCTION}

${ }^{226} \mathrm{Ra}$, with a half-life of 1622 years, has been widely used as a tracer in the oceans for mixing and circulation studies (e.g., Koczy, 1958; Broecker et al., 1967; Ku et al., 1970; Chung and Craig, 1973). Large-scale systematic measurements of ${ }^{226} \mathrm{Ra}$ were undertaken in the GEOSECS (Geochemical Ocean Sections Study) program which encompassed the Atlantic, Indian, Pacific and Circumpolar Oceans (Broecker et al., 1976; Ku and Lin, 1976; Chung and Craig, 1980; Ku et al., 1980; Chung, 1984; Ku and Luo, 1994). ${ }^{226} \mathrm{Ra}$ studies were also extended to the marginal seas including marshes and estuaries (e.g., Elsinger and Moore, 1980; Moore, 1981; Fanning et al., 1982; Elsinger and Moore, 1983; Bollinger and Moore, 1984; Elsinger and Moore, 1984; Harada and Tsunogai, 1986).

The Kuroshio is a warm, saline western boundary current flowing northward along the east coast of Taiwan (Nitani, 1972). Upon reaching the continental margin off northeastern Taiwan, it turns northeastward and also intrudes into the East China Sea, creating a frontal zone mixing and upwelling of the subsurface water in the area (Fan, 1980; Liu, 1983; Liu and Pai, 1987; Chem and Wang, 1989; Wong et al., 1991; Liu et al., 1992). It should be of great interest to see how ${ }^{226} \mathrm{Ra}$ behaves and distributes under the influence of the Kuroshio and its exchange with the ambient water. Furthermore, the extent of radioactive disequilibrium between ${ }^{210} \mathrm{~Pb}$ and ${ }^{226} \mathrm{Ra}$ in the Kuroshio water may provide some insights into the particulate scavenging mechanism as influenced, by the advective and upwelling processes. However, until now no ${ }^{226} \mathrm{Ra}$ data have been collected in the southern Kuroshio water near Taiwan.

The purpose of this paper is to present for the first time the results of ${ }^{226} \mathrm{Ra}$ measurements made on water samples collected from the Kuroshio off eastern and northeastern Taiwan on the KEEP-MASS (Kuroshio Edge Exchange Processes-Marginal Sea Study) cruise of the Russian $R / V$ Vinogradov in July-August, 1992, and on three cruises of the $R / V$ Ocean Researcher I in 1992 and 1993. Besides discussing the ${ }^{226} \mathrm{Ra}$ results in relation to hydrography, the authors also re-evaluate the status of radioactive disequilibrium between ${ }^{210} \mathrm{~Pb}$ and ${ }^{226} \mathrm{Ra}$ at several stations with special attention to the ${ }^{210} \mathrm{~Pb}$ excess in surface and subsurface waters based on the ${ }^{226} \mathrm{Ra}$ data in this study and the published ${ }^{210} \mathrm{~Pb}$ data (Lin and Chung, 1991; Yang and Lin, 1992).

\section{SAMPLE COLLECTIONS AND MEASUREMENTS}

Seawater samples of 20-liter size were collected during the KEEP-MASS cruise in JulyAugust, 1992 and three other Ocean Researcher I (OR1) cruises in 1992 and 1993 (Cruise 314 in April and Cruise 338 in December, 1992, and Cruise 348 in March, 1993). The 


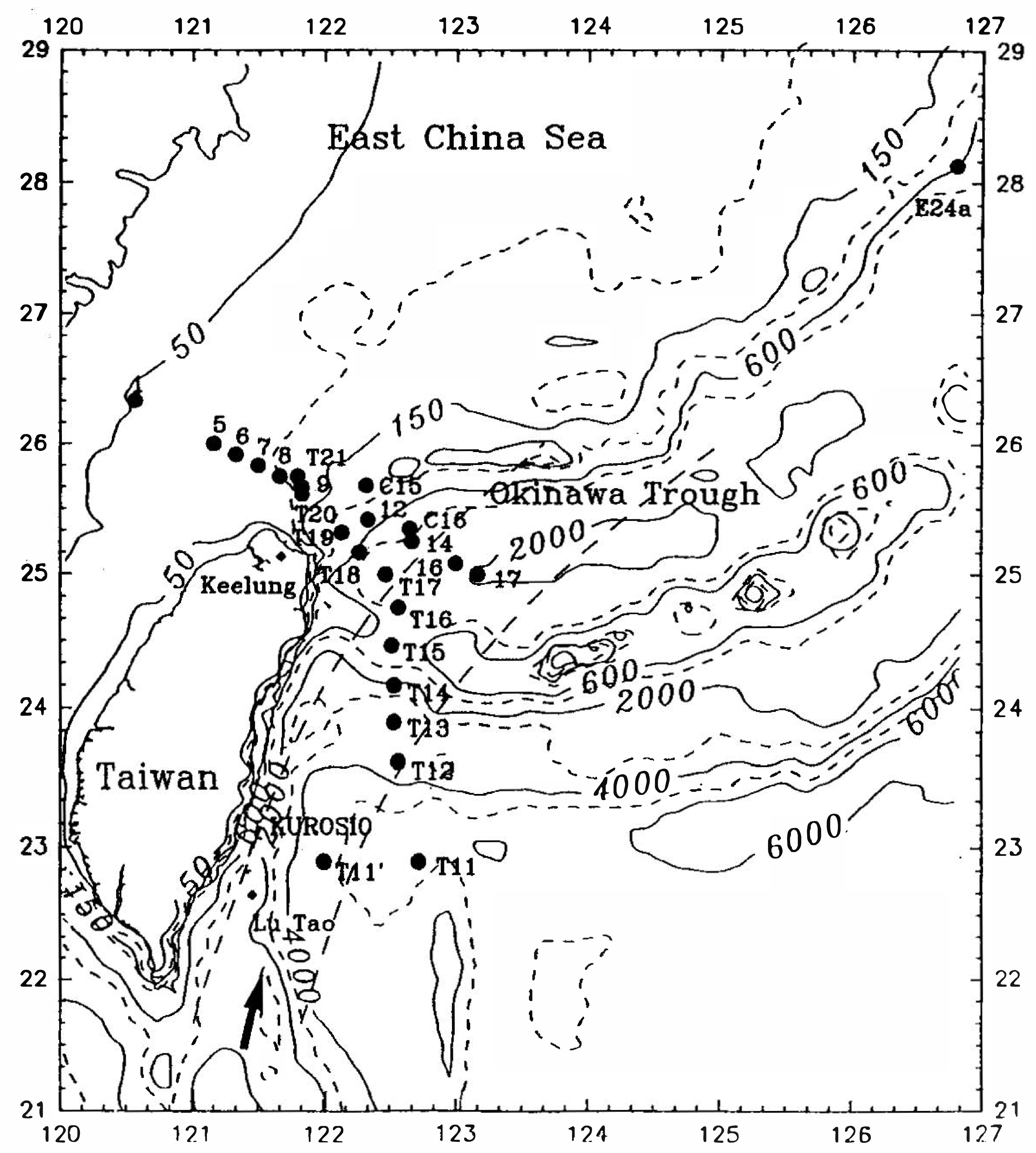

Fig. 1. Station locations for Ra-226 measurements. Station number prefixed with a $\mathrm{T}$ (except T11') or an $\mathrm{E}$ was occupied by the $R / V$ Vinogradov for the KEEP-MASS program. The Kuroshio path and its direction are indicated.

sampling stations are shown in Figure 1 with the number having the prefix of $\mathrm{T}$ or $\mathrm{E}$ (except for T11') indicating a KEEP-MASS station. All the rest are stations occupied during the OR1 cruises.

The surface water samples were collected using either a plastic bucket (OR1 Cruise 314 and Cruise 338, nominal depth $=0 \mathrm{~m}$ ) or a 20-1 GoFlo bottle mounted on a hydrowire and tripped at $4 \mathrm{~m}$ (KEEP-MASS cruise). Each water column sample from station 14 (Cruise 314) was collected using 10 Niskin bottles of 2.5-1 size mounted on a CTD rosette; the KEEPMASS profile samples were collected with 20-1 GoFlo bottles mounted on a hydrowire and tripped at the nominal depth. The remaining water column samples (C15, C16, T11') were collected with 20-1 GoFlo bottles on a CTD rosette. The water depth of these stations ranges from about $100 \mathrm{~m}$ to over $4500 \mathrm{~m}$.

The collected samples were transferred on board to acid-cleaned 20-1 plastic containers to be shipped back to the laboratory where they were transferred into pre-cleaned 20-l thickwall plastic bottles. Each of the bottles had an air-tight cap with a gas inlet and outlet. The inlet tube was attached to an air bubbler. After being transferred into the bottle, the sample was first bubbled with helium as a carrier gas to remove all the radon $\left({ }^{222} \mathrm{Rn}\right)$ and other dissolved gases and then sealed for ingrowth of ${ }^{222} \mathrm{Rn}$ from ${ }^{226} \mathrm{Ra}$ decay. 
About a month later when ${ }^{222} \mathrm{Rn}$ and ${ }^{226} \mathrm{Ra}$ were in secular equilibrium, the ${ }^{222} \mathrm{Rn}$ in the bottle was stripped out again for measurement of the activities of radon and its two shortlived alpha daughters using an alpha scintillation counter. Radon extraction and purification were both performed using a radon stripping board designed at Scripps for the GEOSECS ${ }^{226} \mathrm{Ra}$ program (Chung and Craig, 1980). The technique used for the ${ }^{226} \mathrm{Ra}$ measurement by the regenerated radon method and associated data reduction, etc. were previously described in detail (Chung, 1971). The ${ }^{226} \mathrm{Ra}$ standards used for calibration are those of NIST (NBS) used in the GEOSECS program. The overall precisions of the data presented here are better than $\pm 10 \%$ based on duplicate measurements.

\section{SURFACE WATER ${ }^{226}$ Ra VARIATION}

Results of the ${ }^{226} \mathrm{Ra}$ measurements for the surface water samples together with temperature and salinity are given in Table 1 . Each ${ }^{226} \mathrm{Ra}$ value listed in the table represents the

Table 1. Ra-226 in surface water off eastern and northeastern Taiwan.

\begin{tabular}{|c|c|c|c|c|}
\hline Location & $\operatorname{Depth}(\mathrm{M})^{*}$ & $\operatorname{Temp}\left({ }^{\circ} \mathrm{C}\right)$ & Sal(psu) & Ra-226(dpm/100kg) \\
\hline \multicolumn{5}{|c|}{ OR 1 Cruise 314 (4/16-4/22/1992) } \\
\hline $1\left(26^{\circ} 20^{\prime} \mathrm{N} 120^{\circ} 34^{\prime} \mathrm{E}\right)$ & 0 & 15.896 & 32.001 & $12.2 \pm 0.6$ \\
\hline $5\left(26^{\circ} 00^{\prime} \mathrm{N} 121^{\circ} 10^{\prime} \mathrm{E}\right)$ & 0 & 22.266 & 34.446 & $9.2 \pm 0.6$ \\
\hline $6\left(25^{\circ} 55^{\prime} \mathrm{N} 121^{\circ} 20^{\prime} \mathrm{E}\right)$ & 0 & 21.632 & 34.362 & $10.4 \pm 0.5$ \\
\hline $7\left(25^{\circ} 50^{\prime} \mathrm{N} 121^{\circ} 30^{\prime} \mathrm{E}\right)$ & 0 & 19.493 & 34.263 & $7.0 \pm 0.5$ \\
\hline $8\left(25^{\circ} 45^{\prime} \mathrm{N} 121^{\circ} 40^{\prime} \mathrm{E}\right)$ & 0 & 20.042 & 34.244 & $8.7 \pm 0.4$ \\
\hline $9\left(25^{\circ} 40^{\prime} \mathrm{N} 121^{\circ} 50^{\prime} \mathrm{E}\right)$ & 0 & 20.400 & 34.134 & $6.1 \pm 0.5$ \\
\hline $12\left(25^{\circ} 25^{\prime} \mathrm{N} 122^{\circ} 20^{\prime} \mathrm{E}\right)$ & 0 & 21.827 & 34.476 & $11.9 \pm 0.8$ \\
\hline $14\left(25^{\circ} 15^{\prime} \mathrm{N} 122^{\circ} 40^{\prime} \mathrm{E}\right)$ & 0 & 25.494 & 34.565 & $6.8 \pm 0.5$ \\
\hline $16\left(25^{\circ} 05^{\prime} \mathrm{N} 123^{\circ} 00^{\prime} \mathrm{E}\right)$ & 0 & 25.469 & 34.749 & $7.7 \pm 0.4$ \\
\hline $17\left(25^{\circ} 00^{\prime} \mathrm{N} 123^{\circ} 10^{\prime} \mathrm{E}\right)$ & 0 & 23.432 & 34.731 & $9.9 \pm 0.3$ \\
\hline \multicolumn{5}{|c|}{ RV Vinogradov KEEP-MASS Cruise (7/10/-8/5/1992) } \\
\hline $\mathrm{T} 12\left(23^{\circ} 37^{\prime} \mathrm{N} 122^{\circ} 34^{\prime} \mathrm{E}\right)$ & 4 & & & $7.2 \pm 0.2$ \\
\hline $\mathrm{T} 13\left(23^{\circ} 54^{\prime} \mathrm{N} 122^{\circ} 32^{\prime} \mathrm{E}\right)$ & 4 & 28.04 & 34.611 & $7.7 \pm 0.4$ \\
\hline 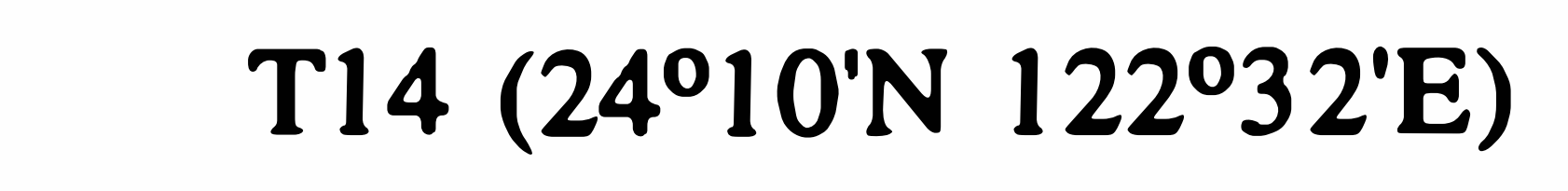 & 4 & 27.87 & 34.612 & $8.1 \pm 0.7$ \\
\hline T15 (24ํㄹ' N $\left.122^{\circ} 31^{\prime} \mathrm{E}\right)$ & 4 & 29.00 & 34.205 & $8.2 \pm 0.4$ \\
\hline 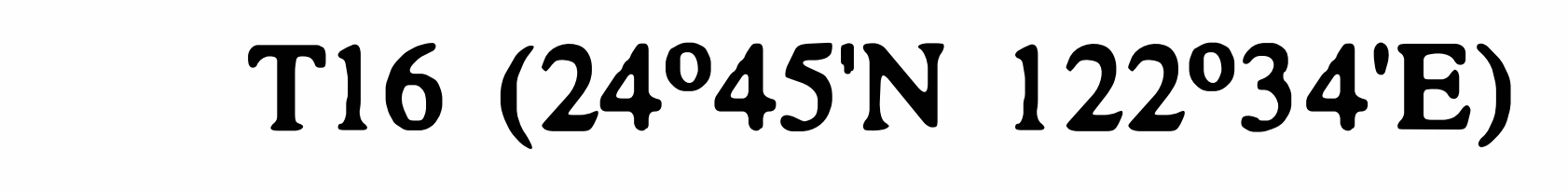 & 4 & & & $12.8 \pm 0.5$ \\
\hline $\mathrm{T} 17\left(25^{\circ} 00^{\prime} \mathrm{N} 12^{\circ} 28^{\prime} \mathrm{E}\right)$ & 4 & 28.06 & 34.190 & $8.3 \pm 0.5$ \\
\hline $\mathrm{T} 18\left(25^{\circ} 10^{\prime} \mathrm{N} 122^{\circ} 16^{\prime} \mathrm{E}\right)$ & 4 & 26.71 & 34.183 & $9.3 \pm 0.3$ \\
\hline  & 4 & & & $6.6 \pm 0.2$ \\
\hline 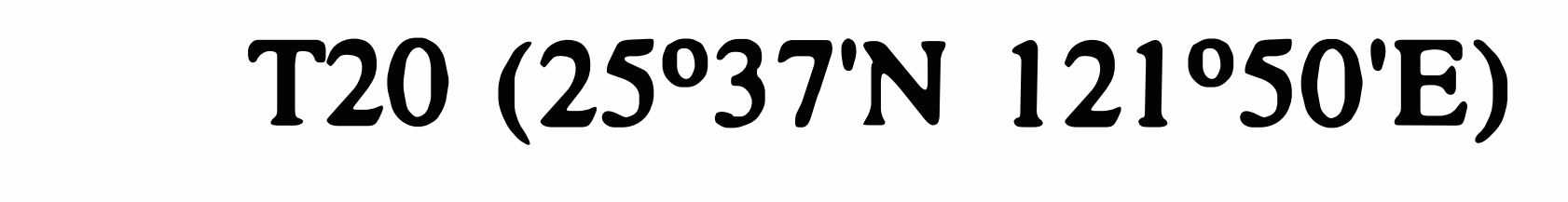 & 4 & 27.88 & 33.852 & $8.5 \pm 0.4$ \\
\hline $\mathrm{T} 21\left(25^{\circ} 45^{\prime} \mathrm{N} 121^{\circ} 48^{\prime} \mathrm{E}\right)$ & 4 & & & $6.5 \pm 0.2$ \\
\hline $\begin{array}{l}\text { E24a }\left(28^{\circ} 08^{\prime} \mathrm{N} 126^{\circ} 48^{\prime} \mathrm{E}\right) \\
\text { OR } 1 \text { Cruise } 338(12 / 3-12 / 8 / 1\end{array}$ & 92) 4 & 28.93 & 34.236 & $6.6 \pm 0.5$ \\
\hline $\mathrm{Cl} 5\left(25^{\circ} 41^{\prime} \mathrm{N} 122^{\circ} 19^{\prime} \mathrm{E}\right)$ & 0 & & & $8.2 \pm 0.4$ \\
\hline $\begin{array}{l}\mathrm{Cl}\left(25^{\circ} 21^{\prime} \mathrm{N} 122^{\circ} 39^{\prime} \mathrm{E}\right) \\
\text { OR } 1 \text { Cruise } 348(3 / 19-3 / 25 / 1\end{array}$ & 93) 0 & & & $8.2 \pm 0.6$ \\
\hline $\mathrm{T}_{11} 1^{\prime}\left(22^{\circ} 54^{\prime} \mathrm{N} 12^{\circ} 00^{\prime} \mathrm{E}\right)$ & 4 & & & $6.9 \pm 0.3$ \\
\hline
\end{tabular}

${ }^{*} 0 \mathrm{M}$ : collected with plastic buckets

$4 \mathrm{M}$ : collected with GoFlo bottles 
mean of the duplicate measurements; the error quoted for the mean is one standard deviation of the repeated measurements or of the overall counting statistics, whichever is greater. No hydrographic data are available for several stations of the KEEP-MASS cruise and all the stations of the Cruises 338 and 348. The KEEP-MASS temperature data were reported to one hundredth of a degree centigrade (Chen, 1992). Station 14 of Cruise 314 is also a profile station ; E24a is a profile station from the East China Sea.

Figure 2 shows the surface water ${ }^{226} \mathrm{Ra}$ and temperature distributions off northern and eastern Taiwan. The spatial variations in both temperature and ${ }^{226} \mathrm{Ra}$ are quite random, showing neither a coherent relationship nor a systematic trend. The ${ }^{226} \mathrm{Ra}$ concentrations vary between 6.1 and $12.8 \mathrm{dpm} / 100 \mathrm{~kg}$; large differences relative to the measurement errors among adjacent stations are often observed. In the upwelling cold dome north of Keelung (Fan, 1980; Liu, 1983; Liu and Pai, 1987; Liu et al., 1992), the ${ }^{226} \mathrm{Ra}$ values are somewhat lower rather than higher compared to those near the mainland China and on the Kuroshio. A vague trend of a northward increase is discernible along the east coast of Taiwan.

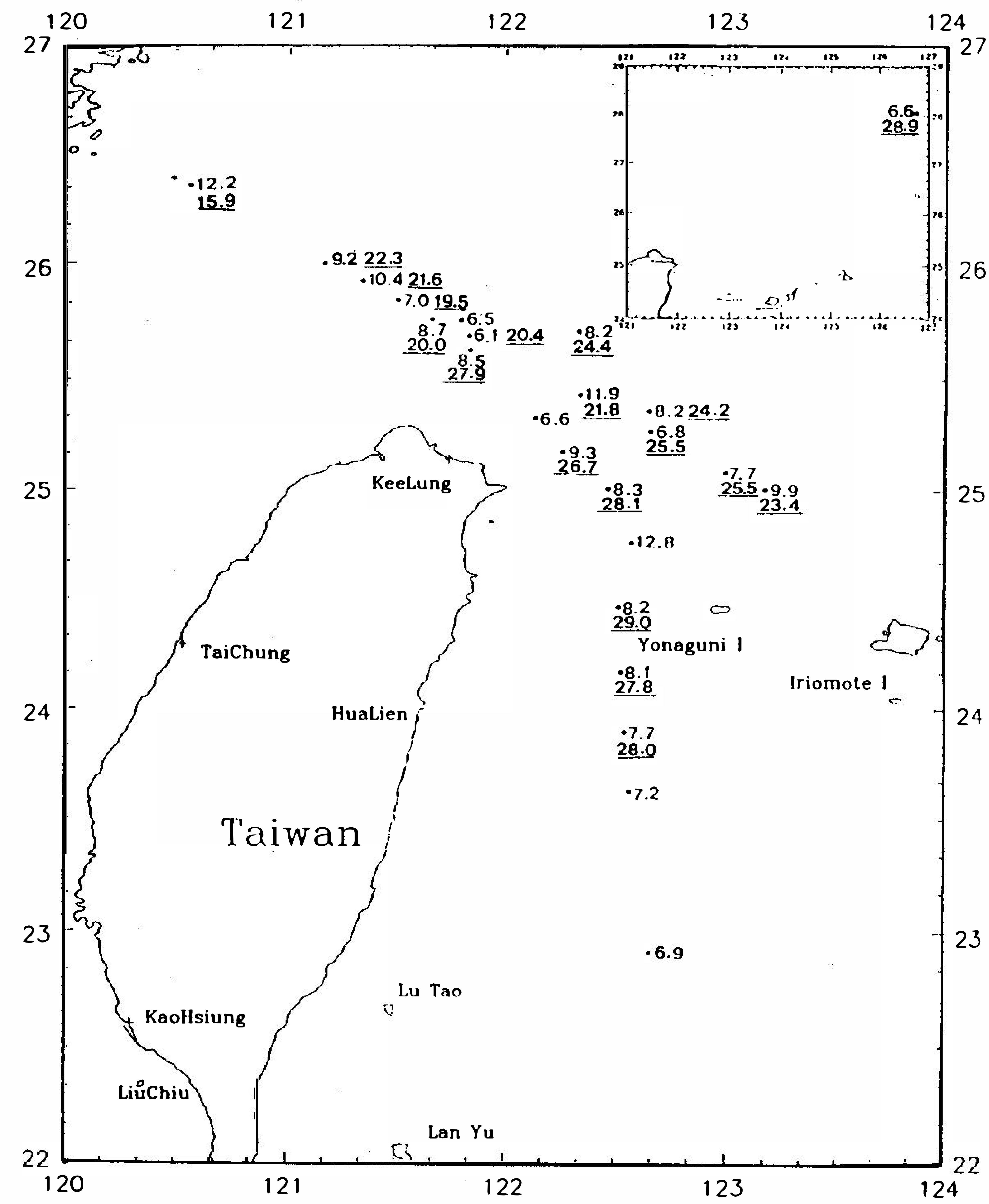

Fig. 2. Surface water temperature and Ra-226 distributions off eastern and northeastern Taiwan. The temperature values are underlined. 
Both features appear to be contradictory to the conventional wisdom that the ${ }^{226} \mathrm{Ra}$ concentration gradient, if any, should be in the west to east rather than in the north to south direction in the Kuroshio east of Taiwan and that the ${ }^{226} \mathrm{Ra}$ should be higher rather than lower in the upwelling area. Thus, a more closely-spaced sampling within a cruise or short period is needed to resolve the details.

The surface water ${ }^{226} \mathrm{Ra}$ in the study area has a large variation that is not observed in the surface water of any open oceans where ${ }^{226} \mathrm{Ra}$ usually varies between 6 and $8 \mathrm{dpm} / 100$ kg (Broecker et al., 1976; Chung and Craig, 1980; Ku et al., 1980). However, the observed variation, albeit random and large, is somewhat similar to that observed in the northern East China Sea by Nozaki (1989). Marginal seas have a higher surface water ${ }^{226} \mathrm{Ra}$ variation probably due to localized river fluxes and diffusion from different bottom sediments as well as from coastal zones of various landmass. A large random spatial variation in surface water ${ }^{226} \mathrm{Ra}$ content warrants a further detailed investigation.

\section{HYDROGRAPHY}

Figure 3 shows composite potential temperature, salinity, dissolved oxygen, and silicate profiles from stations T11, T14, T17 and 14 roughly along the path of Kuroshio from south to north (Figure 1). Although quite scattered, these profiles basically show some common gross hydrographic features, i.e. a sharp subsurface salinity maximum $(\sim 200 \mathrm{~m})$, a salinity minimum near $500 \mathrm{~m}$ depth (Figure 3B), and an oxygen minimum around $800 \mathrm{~m}$ depth (Figure 3C). Dissolved oxygen and silicate profiles (Figures 3C and 3D) may be grouped into two types: the stations at the south and the center (T11, T14) show higher dissolved oxygen and lower silicate, while the stations farther north $(T 17,14)$ show lower dissolved oxygen and higher silicate above the depth of the salinity minimum. It is not clear why these changes take place within a short distance of $90 \mathrm{~km}$ along and within the Kuroshio (Figure 1) between T14 and T17, since about $150 \mathrm{~km}$ to the south of T14 and away from the Kuroshio path, T11 shows the same profile characteristics as T14.

The secondary features revealed in Figure 3 are: the potential temperature profiles of T11 and T14 are identical while that of T17 has a higher temperature below the depth of 500 $\mathrm{m}$ and a lower temperature above this depth (Figure 3A); the salinity profiles of T11 and T14 match fairly well above the salinity minimum but below this, T14 has higher values (Figure 3B); the salinity profiles of T17 and 14 are identical and show a lower salinity maximum and higher salinity minimum, suggesting a northward "erosion" of the extrema; the dissolved oxygen minima at T11 and T14 are lower than those at T17 and 14, also showing a northward erosion or the effect of vertical mixing.

These hydrographic profiles appear to be inconsistent with the conventional wisdom which would predict no significant hydrographic variations within a relatively short distance along the advective path of the Kuroshio. The changes of all the hydrographic parameters take place between T14 and T17. A detailed CTD profiling between these two stations is required to verify there changes. However, these features are not inconsistent with the ${ }^{226} \mathrm{Ra}$ profiles which show a northward increase from T11, via T14 to T17 and 14 at the corresponding depth range (see the next section).

\section{5. ${ }^{226}$ Ra PROFILES}

Data for all the ${ }^{226} \mathrm{Ra}$ profiles and associated temperature and salinity are listed in Table 2. The ${ }^{226} \mathrm{Ra}$ values are, like those of the surface water listed in Table 1 , mean values of duplicate measurements, and the errors quoted are obtained identically. No hydrographic 



Fig. 3. Composite potential temperature, salinity, dissolved oxygen and silicate profiles from stations T11, T14, T17 and 14.

data are available at stations C15, C16 (Cruise 338) and T11' (Cruise 348). The potential temperature data from the KEEP-MASS Cruise are also reported to one hundredth of a degree centigrade.

Figure 4 shows all the ${ }^{226} \mathrm{Ra}$ profiles in the three different depth scales in order to better visualize the depth distribution. Four shallow water profiles on the shelf and upper slope areas are shown in Figure 4A with the ${ }^{226} \mathrm{Ra}$ concentrations being fairly uniform at 10 $\mathrm{dpm} / 100 \mathrm{~kg}$ to the depth of $400 \mathrm{~m}$. Six intermediate and deep water profiles on the lower slope and deep basin are plotted in Figure 4B down to $1500 \mathrm{~m}$. Within the water depth between $300 \mathrm{~m}$ and $1000 \mathrm{~m}$, the ${ }^{226} \mathrm{Ra}$ values are quite scattered among different profiles. However, a northward increasing trend can be seen: T11 and T11' at the south have lower ${ }^{226} \mathrm{Ra}$ values; $\mathrm{T} 14$ at the center has intermediate values; and the remaining profiles (T17, 14, $\mathrm{Cl6}$ ) at the north have higher values. This trend is in line with that observed on the surface water (Figure 2) although the profiles are essentially identical above $200 \mathrm{~m}$ (Figure 4B). The deep profiles (T11 and T11') as shown in Figure 4C indicate a gradual increase from about $12 \mathrm{dpm} / 100 \mathrm{~kg}$ at $1000 \mathrm{~m}$ to about $30 \mathrm{dpm} / 100 \mathrm{~kg}$ at $2500 \mathrm{~m}$. Below $2500 \mathrm{~m}$, the ${ }^{226} \mathrm{Ra}$ concentrations are fairly constant at around $30 \mathrm{dpm} / 100 \mathrm{~kg}$. The low value at $4000 \mathrm{~m}(\mathrm{~T} 11,25$ $\mathrm{dpm} / 100 \mathrm{~kg}$ ) may be problematic, when it is judged from all the other values below $2500 \mathrm{~m}$, 
Table 2. Water column data of Ra-226 off eastern and northeastern Taiwan.

\begin{tabular}{|c|c|c|c|c|}
\hline \multirow{2}{*}{\multicolumn{5}{|c|}{ 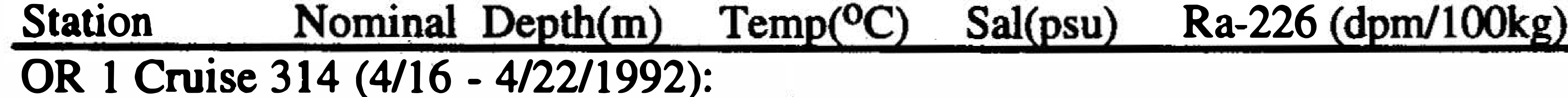 }} \\
\hline & & & & \\
\hline \multicolumn{5}{|c|}{$14\left(25^{\circ} 15^{\prime} \mathrm{N} 122^{\circ} 40^{\prime} \mathrm{E} ; 979 \mathrm{~m}\right)$} \\
\hline & 0 & 25.494 & 34.565 & $6.8 \pm 0.5$ \\
\hline & 75 & 23.019 & 34.649 & $8.8 \pm 0.5$ \\
\hline & 100 & 20.911 & 34.583 & $8.7 \pm 0.4$ \\
\hline & 300 & 13.162 & 34.521 & $12.1 \pm 0.6$ \\
\hline & 600 & 6.208 & 34.342 & $14.8 \pm 0.7$ \\
\hline & 800 & 5.215 & 34.414 & $13.0 \pm 0.5$ \\
\hline \multicolumn{5}{|c|}{ RV Vinogradov KEEP-MASS Cruise (7/10 - 8/5/1992): } \\
\hline \multicolumn{5}{|c|}{ 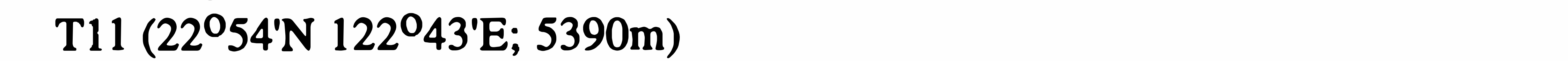 } \\
\hline & 200 & 17.26 & 34.807 & $6.8 \pm 0.5$ \\
\hline & 400 & 10.04 & 34.308 & $7.5 \pm 0.5$ \\
\hline & 600 & 5.83 & 34.298 & $7.6 \pm 0.6$ \\
\hline & 1500 & 2.35 & 34.595 & $19.5 \pm 1.1$ \\
\hline & 2000 & 1.81 & 34.640 & $24.9 \pm 1.2$ \\
\hline & 3000 & 1.35 & 34.679 & $31.4 \pm 2.1$ \\
\hline & 4000 & 1.20 & 34.691 & $25.0 \pm 0.8$ \\
\hline \multicolumn{5}{|c|}{$\mathrm{T} 14\left(24^{\circ} 10^{\prime} \mathrm{N} 122^{\circ} 32^{\prime} \mathrm{E} ; 1310 \mathrm{~m}\right)$} \\
\hline & 4 & 27.87 & 34.612 & $8.1 \pm 0.7$ \\
\hline & 50 & 27.87 & 34.612 & $6.7 \pm 0.6$ \\
\hline & 200 & 18.03 & 34.897 & $8.2 \pm 0.6$ \\
\hline & 400 & 14.60 & 34.607 & $11.1 \pm 0.6$ \\
\hline & 600 & 9.25 & 34.286 & $12.5 \pm 0.8$ \\
\hline & 1000 & 4.30 & 34.464 & $16.9 \pm 0.9$ \\
\hline \multicolumn{5}{|c|}{$\mathrm{T} 17\left(25^{\circ} 00^{\prime} \mathrm{N} 122^{\circ} 28^{\prime} \mathrm{E} ; 1430 \mathrm{~m}\right)$} \\
\hline & 4 & 28.06 & 34.190 & $8.3 \pm 0.5$ \\
\hline & 20 & 25.86 & 34.305 & $8.3 \pm 0.3$ \\
\hline & 50 & 23.60 & 34.465 & $7.9 \pm 0.6$ \\
\hline & 100 & 20.26 & 34.611 & $9.6 \pm 0.5$ \\
\hline & 200 & 15.67 & 34.652 & $8.2 \pm 0.5$ \\
\hline & 300 & 13.52 & 34.546 & $11.9 \pm 0.8$ \\
\hline & 400 & 11.48 & 34.441 & $13.2 \pm 0.7$ \\
\hline & 500 & 9.58 & 34.379 & $18.2 \pm 0.7$ \\
\hline & 800 & 6.38 & 34.378 & $18.7 \pm 1.1$ \\
\hline & 1200 & 4.39 & 34.424 & $21.6 \pm 0.4$ \\
\hline & 1400 & & & $23.2 \pm 0.5$ \\
\hline \multicolumn{5}{|c|}{$\mathrm{T} 18\left(25^{\circ} 10^{\prime} \mathrm{E} 122^{\circ} 16^{\prime} \mathrm{E} ; 230 \mathrm{~m}\right)$} \\
\hline & 4 & 26.71 & 34.183 & $9.3 \pm 0.3$ \\
\hline & 50 & 23.18 & 34.407 & $9.1 \pm 0.3$ \\
\hline & 200 & 12.44 & 34.487 & $13.5 \pm 0.4$ \\
\hline \multicolumn{5}{|c|}{$\mathrm{T} 20\left(25^{\circ} 36^{\prime} \mathrm{N} 121^{\circ} 49^{\prime} \mathrm{E} ; 120 \mathrm{~m}\right)$} \\
\hline & 4 & 27.88 & 33.852 & $8.5 \pm 0.4$ \\
\hline & 50 & 24.18 & 34.127 & $9.5 \pm 0.4$ \\
\hline & 100 & 15.98 & 34.575 & $8.8 \pm 0.5$ \\
\hline \multicolumn{5}{|c|}{ E24a $\left(28^{\circ} 08^{\prime} \mathrm{N} 126^{\circ} 48^{\prime} \mathrm{E} ; 450 \mathrm{~m}\right)$} \\
\hline & 4 & 28.93 & 34.237 & $6.6 \pm 0.5$ \\
\hline & 50 & 25.83 & 34.316 & $9.0 \pm 0.5$ \\
\hline & 300 & 12.08 & 34.461 & $10.9 \pm 0.6$ \\
\hline & 400 & 8.45 & 34.269 & $11.9 \pm 0.6$ \\
\hline
\end{tabular}


Table 2. (Continued)

\begin{tabular}{|c|c|c|c|}
\hline \multirow{2}{*}{\multicolumn{2}{|c|}{$\begin{array}{ll}\text { Station } & \text { Nominal } \\
\text { OR } 1 \text { Cruise } 338(12 / 3-12 / 8 / 1992\end{array}$}} & Temp $\left({ }^{\circ} \mathrm{C}\right) \quad$ Sal(psu) & Ra-226 (dpm/100kg) \\
\hline & & & \\
\hline \multicolumn{4}{|c|}{$\mathrm{C} 15\left(25^{\circ} 42^{\prime} \mathrm{N} 122^{\circ} 20^{\prime} \mathrm{E} ; 108 \mathrm{~m}\right)$} \\
\hline & 0 & & $8.2 \pm 0.4$ \\
\hline & 30 & & $7.8 \pm 0.3$ \\
\hline & 50 & & $9.9 \pm 0.5$ \\
\hline & 80 & & $8.2 \pm 0.4$ \\
\hline & 100 & & $9.7 \pm 0.3$ \\
\hline \multicolumn{4}{|c|}{$\mathrm{Cl} 6\left(25^{\circ} 21^{\prime} \mathrm{N} 122^{\circ} 39^{\prime} \mathrm{E} ; 741 \mathrm{~m}\right)$} \\
\hline & 0 & & $8.2 \pm 0.6$ \\
\hline & 100 & & $8.3 \pm 0.4$ \\
\hline & 300 & & $9.4 \pm 0.8$ \\
\hline & 500 & & $15.3 \pm 0.6$ \\
\hline & 600 & & $15.0 \pm 0.6$ \\
\hline & 700 & & $21.7 \pm 0.7$ \\
\hline \multicolumn{4}{|c|}{ OR 1 Cruise 348 (3/19 - 3/25/1993): } \\
\hline \multicolumn{4}{|c|}{$\mathrm{T} 11^{\prime}\left(22^{\circ} 54^{\prime} \mathrm{N} 122^{\circ} 00^{\prime} \mathrm{E}_{;} 4800 \mathrm{~m}\right)$} \\
\hline & 4 & & $6.9 \pm 0.3$ \\
\hline & 50 & & $8.2 \pm 0.4$ \\
\hline & 1000 & & $12.5 \pm 0.4$ \\
\hline & 1200 & & $21.3 \pm 0.6$ \\
\hline & 1700 & & $25.3 \pm 0.6$ \\
\hline & 2500 & & $33.1 \pm 1.3$ \\
\hline & 3300 & & $30.2 \pm 0.5$ \\
\hline & 4500 & & $31.2 \pm 0.4$ \\
\hline
\end{tabular}
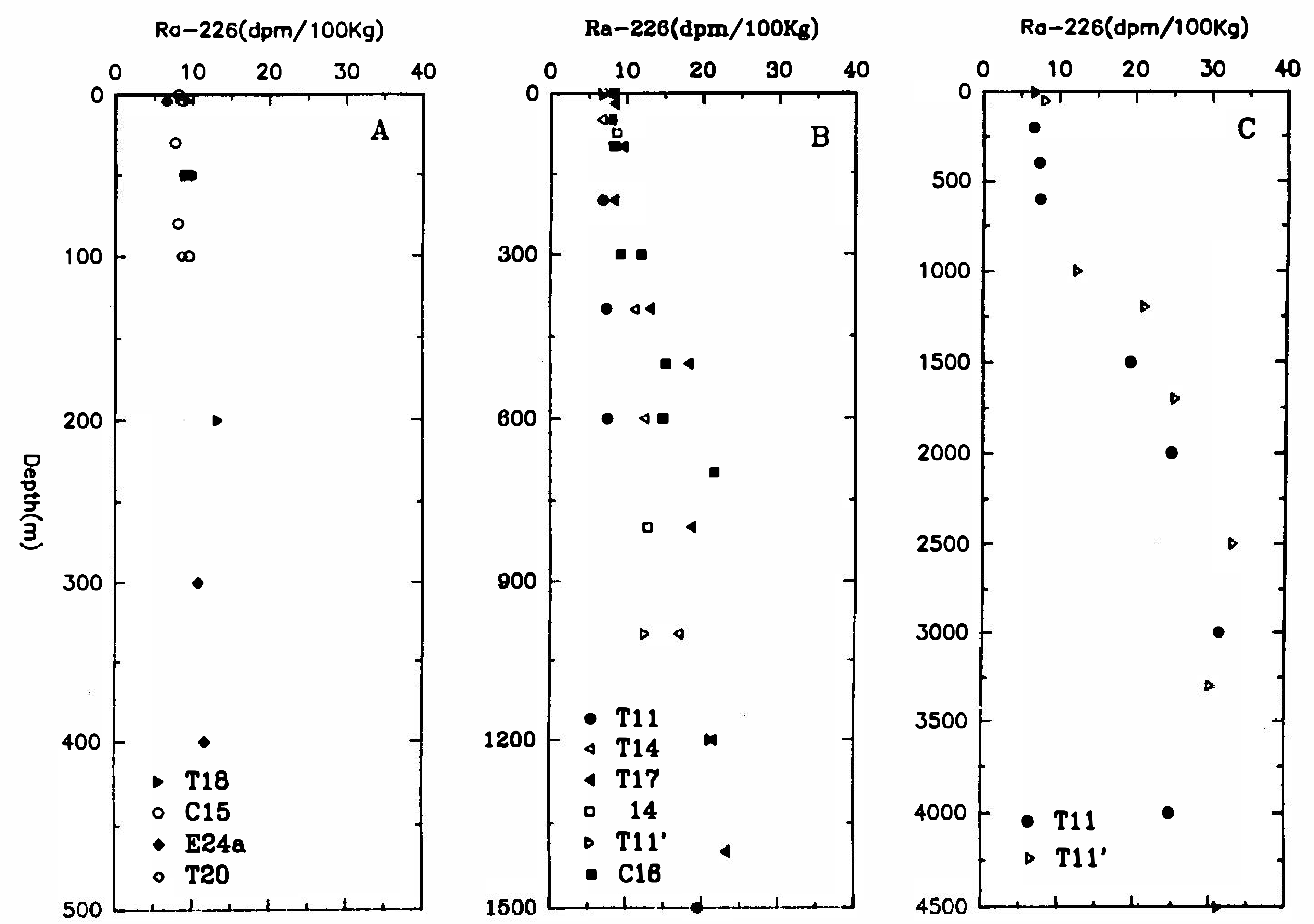

Fig. 4. Ra-226 profiles shown in three different depth-scales. A northward increase in Ra-226 in the intermediate depth between $200 \mathrm{~m}$ and $1000 \mathrm{~m}$ is illustrated in $\mathrm{B}$. 
but it cannot be ruled out as a measurement error. However, the hydrographic data at this station do not support the existence of this minimum. Higher sampling density around this depth together with CTD and other hydrographic observations is required to resolve this problem. If this minimum is real, then it may serve to indicate the spreading of the Antarctic Bottom Water which is known to have a lower ${ }^{226} \mathrm{Ra}$ concentration (Chung and Craig, 1980). The general pattern of the deep water profiles is quite similar to that observed from the deep North Pacific, and the concentration level is consistent with that expected from the known Pacific profiles (Chung and Craig, 1980).

\section{PROPERTY VS PROPERTY RELATIONSHIPS}

As expected from the hydrographic features and ${ }^{226} \mathrm{Ra}$ distributions (Figures 3 and 4), the property vs property plots between parameters can better illustrate the trend or change in their relationships from south to north. Plots of potential temperature vs. salinity (T-S diagrams), salinity vs. dissolved oxygen $\left(\mathrm{S}-\mathrm{O}_{2}\right)$, potential temperature vs. silicate (T-Si), and silicate vs. ${ }^{226} \mathrm{Ra}\left(\mathrm{Si}^{226} \mathrm{Ra}\right)$ are shown for comparisons of stations $\mathrm{T} 11, \mathrm{~T} 14, \mathrm{~T} 17$ and 14 (Figure 5).

The T-S diagrams show that both the salinity maximum and minimum are fairly close for T11 and T14, but this maximum is higher than, and this minimum is lower than that for T17 and 14. These extrema for T17 and 14 are also quite close to each other except for temperatures greater than $18^{\circ} \mathrm{C}$ (Figure 5A). Below the salinity minimum, the plots of T14 are parallel to, and higher than those of T11 mainly due to the higher salinity at T14 (Figure 3). The salinity vs. oxygen plots show a loop due to the fact that the depth of the $\mathrm{O}_{2}$ minimum is greater than that of the $\mathrm{S}$ minimum. The salinity minimum at $\mathrm{T} 17$ and 14 is clearly higher than at T11 and T14 (Figure 5B) as also seen in the TS diagrams.

$\mathrm{T} 17$ is systematically higher than other stations in the T-Si plots (Figure $5 \mathrm{C}$ ) due to the higher $\mathrm{T}$ below $500 \mathrm{~m}$ and the higher $\mathrm{Si}$ above this depth (Figure 3A and 3D). The high $\mathrm{Si}$ content is associated with the high ${ }^{226} \mathrm{Ra}$ concentration as shown in the $\mathrm{Si}^{226}{ }^{26 a}$ plots (Figure 5D). ${ }^{226} \mathrm{Ra}$ shows a large increase from T11 at the south to T17 at the north in the silicate values between 25 and $100 \mu \mathrm{M}$. Such silicate vs. ${ }^{226} \mathrm{Ra}$ relations are far from linearity, suggesting that silicate is not a major carrier for ${ }^{226} \mathrm{Ra}$.

\section{COMPARISONS OF ${ }^{226}$ Ra AND ${ }^{210}$ Pb PROFILES}

The extent of ${ }^{210} \mathrm{~Pb} /{ }^{226} \mathrm{Ra}$ disequilibrium is a useful indicator for the scavenging process and the mean residence time of the particulate matter in the deep oceans (e.g., Craig et al., 1973; Bacon et al., 1976; Chung, 1981; Chung and Craig, 1983; Chung, 1987). There are a few published ${ }^{210} \mathrm{~Pb}$ profiles of the study area (Lin and Chung, 1991; Yang and Lin, 1992). Now that ${ }^{226} \mathrm{Ra}$ profiles are available, it is imperative that the ${ }^{210} \mathrm{~Pb}$ and ${ }^{226} \mathrm{Ra}$ relations be examined. Unfortunately, these ${ }^{226} \mathrm{Ra}$ profiles are neither located at the ${ }^{210} \mathrm{~Pb}$ stations nor were they collected at the same time. It is not yet clear at present whether a steady-state condition can be established for these tracers. Locations of the ${ }^{210} \mathrm{~Pb}$ and ${ }^{226} \mathrm{Ra}$ profiles available for comparison are shown in Figure 6 . The ${ }^{210} \mathrm{~Pb}$ profiles at H16, R19 and R23 were published (Lin and Chung, 1991) as was that at 4531 (Yang and Lin, 1992).

${ }^{210} \mathrm{~Pb}$ is in excess over ${ }^{226} \mathrm{Ra}$ from the surface water down to a few hundred meters due to the atmospheric flux, and it becomes deficient below this depth due to scavenging by 
settling particles. Based on a ${ }^{226} \mathrm{Ra}$ profile calculated from a silicate profile in the Okinawa rough through a linear Ra-Si relationship (Lin and Chung, 1991), the depth of excess ${ }^{210} \mathrm{~Pb}$ penetration was estimated at $500 \mathrm{~m}$. These features are quite similar to those observed in the open oceans except for the penetration depth which is usually about $800 \mathrm{~m}-1000 \mathrm{~m}$ in the open oceans.
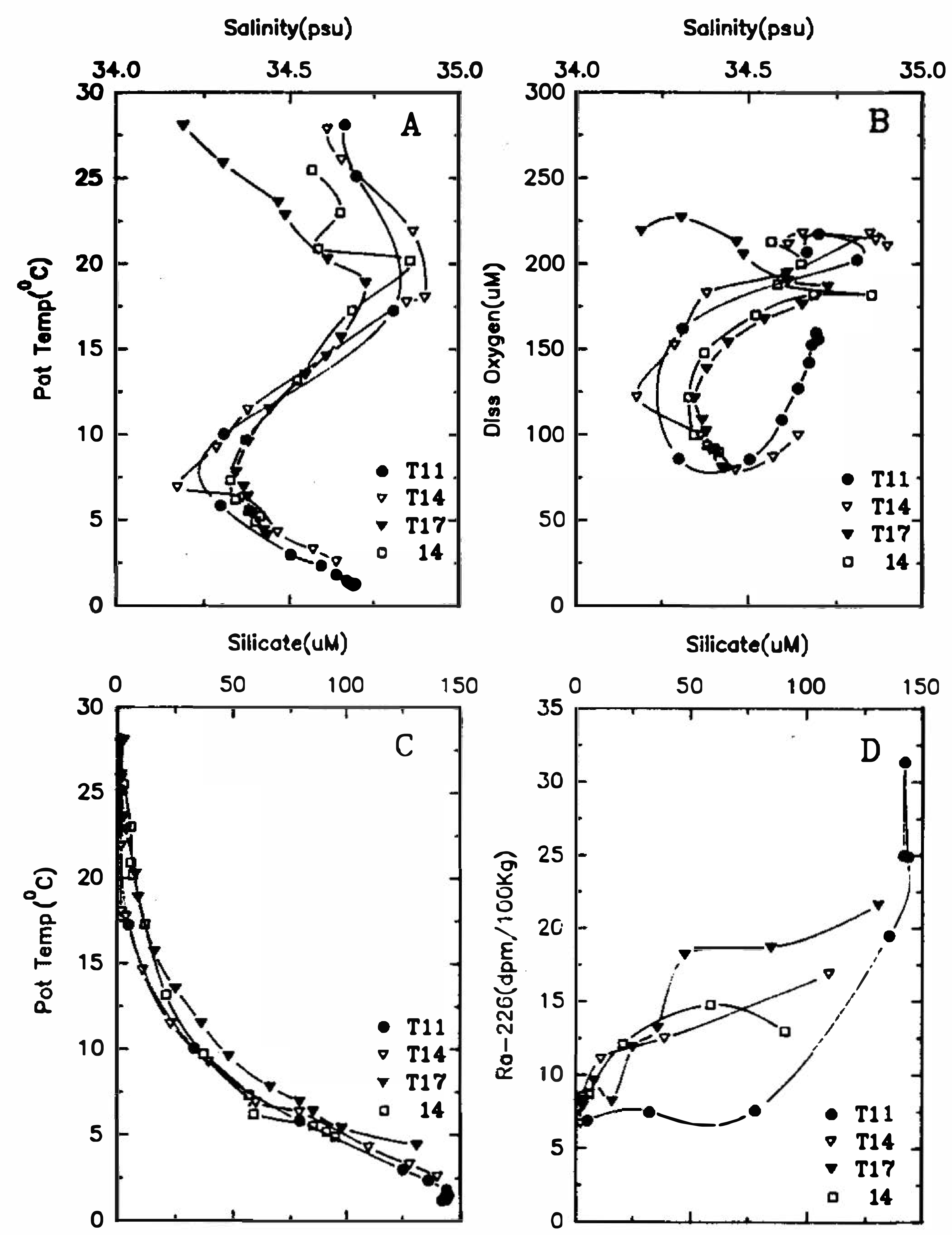

Fig. 5. Composite property vs property plots for potential temperature, salinity, dissolved oxygen, silicate and Ra-226.

Figure 7 shows profiles of ${ }^{210} \mathrm{~Pb}$ and ${ }^{226} \mathrm{Ra}$ from south to north (A to C), nearly along the Kuroshio. The ${ }^{210} \mathrm{~Pb}$ profile at $\mathrm{R} 23$ shows a fairly uniform distribution at about 13 $\mathrm{dpm} / 100 \mathrm{~kg}$ from surface to the depth of $1000 \mathrm{~m}$ (Figure 7A). This ${ }^{210} \mathrm{~Pb}$ profile is entirely different from those farther north which show either a surface or subsurface maximum before decreasing with depth (Figure 7B and 7C). As R23 is located just between T11 (also T11') and T14 (Figure 6), its ${ }^{210} \mathrm{~Pb}$ profile may be compared with the ${ }^{226} \mathrm{Ra}$ profile either from T11 to the south or T14 to the north. As mentioned earlier, these two ${ }^{226} \mathrm{Ra}$ profiles differ quite significantly between the depths of $200 \mathrm{~m}$ and $1000 \mathrm{~m}$; thus, the extent of ${ }^{210} \mathrm{~Pb}$ excess or the inventory of ${ }^{210} \mathrm{~Pb}$ excess estimated from these two profiles also differs significantly. As a matter of fact, the excess ${ }^{210} \mathrm{~Pb}$ inventory based on T11 (and T11') is about $4.4 \mathrm{dpm} / \mathrm{cm}^{2}$, while that based on T14 is only about $1.8 \mathrm{dpm} / \mathrm{cm}^{2}$. The excess ${ }^{210} \mathrm{~Pb}$ at $\mathrm{R} 23$ penetrates 


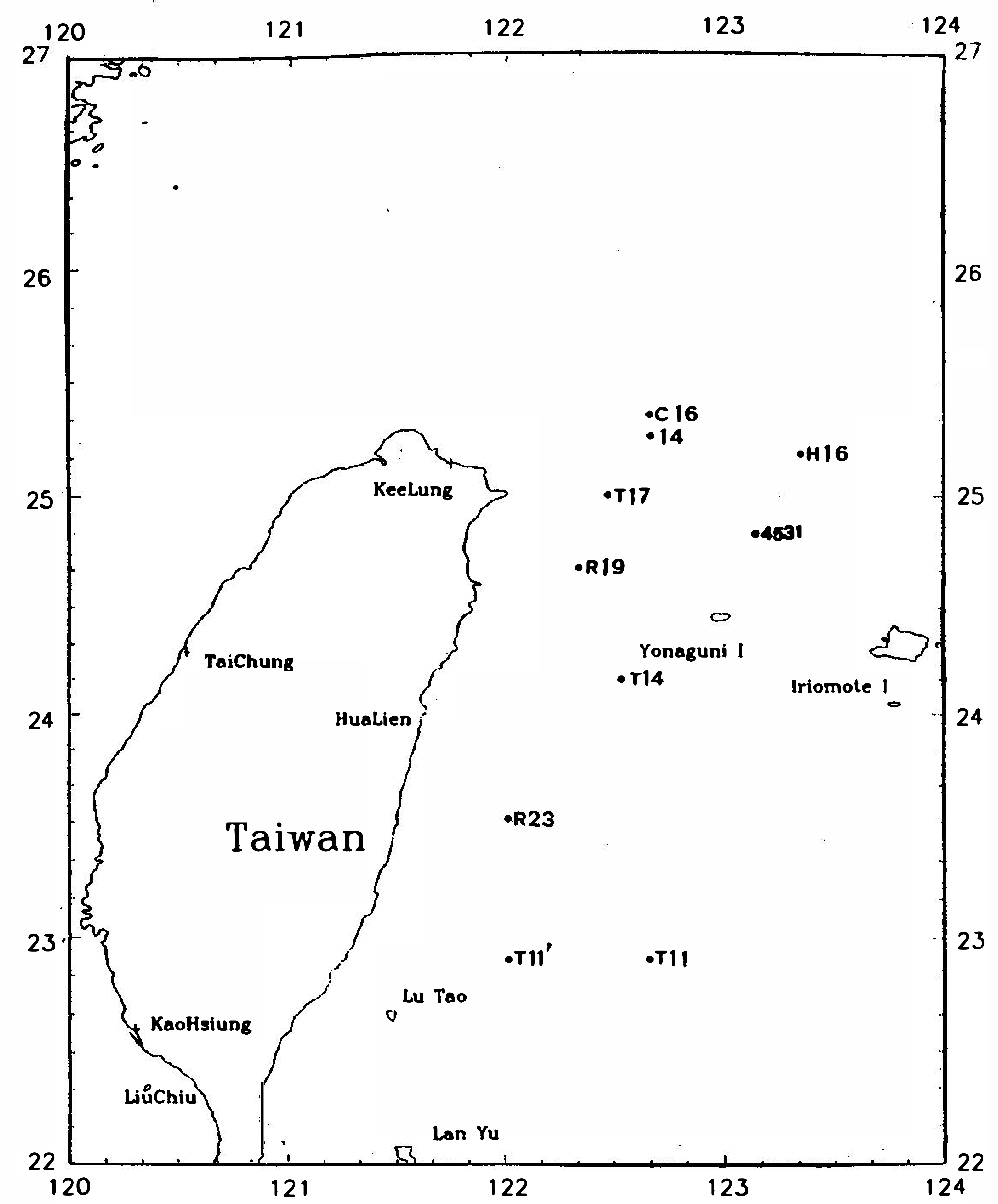

Fig. 6. Map showing station locations of the $\mathrm{Pb}-210$ and $\mathrm{Ra}-226$ profiles used to determine the $\mathrm{Pb}-210$ excess. The $\mathrm{Pb}-210$ profiles are $\mathrm{R} 23, \mathrm{R} 19, \mathrm{H} 16$ and 4531 .

down to $1000 \mathrm{~m}$ based on the ${ }^{226} \mathrm{Ra}$ profile at $\mathrm{T} 1 \mathrm{l}$, but only down to $500 \mathrm{~m}$ based on the profile at T14.

As R19 is located between T14 and T17, its ${ }^{210} \mathrm{~Pb}$ profile is compared either with the ${ }^{226} \mathrm{Ra}$ profile at T14 to the south or T17 to the north (Figure 7B). The ${ }^{210} \mathrm{~Pb}$ profile shows a distinct maximum at the depth of $100 \mathrm{~m}$ rather than at the surface. The two ${ }^{226} \mathrm{Ra}$ profiles are fairly similar above $400 \mathrm{~m}$, but they display large systematic differences below this depth with $\mathrm{T} 17$ being higher. The excess ${ }^{210} \mathrm{~Pb}$ inventory based on ${ }^{226} \mathrm{Ra}$ profiles at $\mathrm{T} 14$ and T17 is about 2.1 and $1.3 \mathrm{dpm} / \mathrm{cm}^{2}$, respectively. The penetration depth of the excess ${ }^{210} \mathrm{~Pb}$ is about $300 \mathrm{~m}$.

The two ${ }^{210} \mathrm{~Pb}$ profiles (H16 and 4531) are similar in showing surface maximum with values significantly higher than those of the other stations to the south (Figure 7). However, these two profiles cross over each other twice, and the lower values are at 4531 below $200 \mathrm{~m}$ depth. The three ${ }^{226} \mathrm{Ra}$ profiles shown in Figure $7 \mathrm{C}$ are located very close to one another but farther away from H16 and 4531 (Figure 6); they are about identical above $500 \mathrm{~m}$ but scattered below. The inventory of excess ${ }^{210} \mathrm{~Pb}$ is about $2.3 \mathrm{dpm} / \mathrm{cm}^{2}$ at $\mathrm{H} 16$ and about 1.7 
$\mathrm{dpm} / \mathrm{cm}^{2}$ at 4531 . The penetration depth is $360 \mathrm{~m}$ at $\mathrm{H} 16$ and $300 \mathrm{~m}$ at 4531 . Below $1000 \mathrm{~m}$ the ${ }^{210} \mathrm{~Pb} /{ }^{226} \mathrm{Ra}$ activity ratio (H16 vs T17) is about 0.25 , corresponding to a scavenging residence time of about 10 yrs. This agrees with the previous estimate by Lin and Chung (1991).
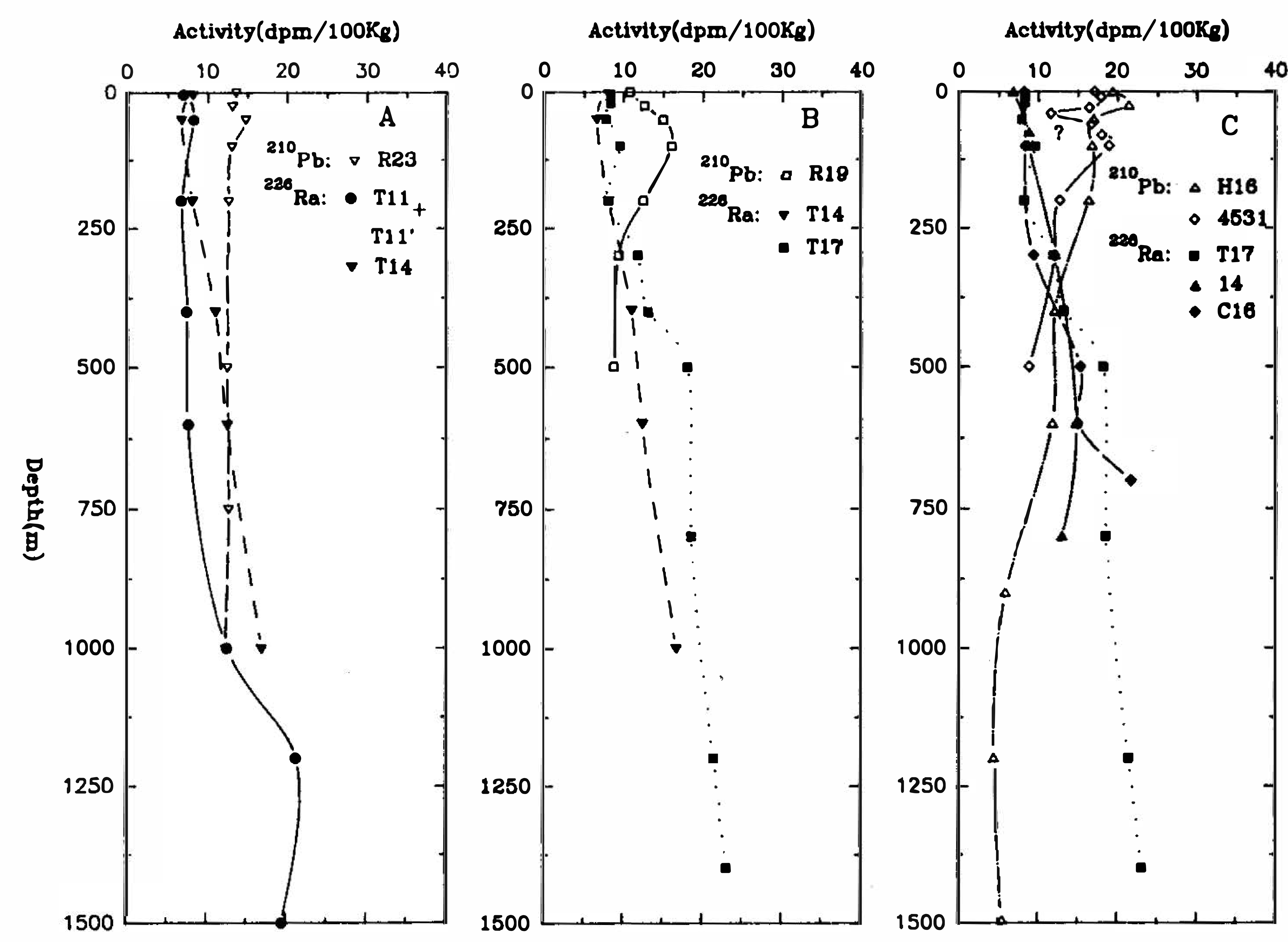

Fig. 7. Comparisons of $\mathrm{Pb}-210$ profiles with their adjacent $\mathrm{Ra}-226$ profiles showing their radioactive disequilibria.

\section{BOX MODEL FOR EXCESS ${ }^{210} \mathrm{~Pb}$ LAYER}

Assuming steady-state conditions in a "box" from the surface to the excess ${ }^{210} \mathrm{~Pb}$ penetration depth, the ${ }^{210} \mathrm{~Pb}$ mass balance in the box can be expressed as

$$
F+\lambda_{P b} I_{R a}=\lambda_{P b} I_{P b}+\Psi I_{P b}
$$

where $F$ is the atmospheric flux (taken to be $1.6 \mathrm{dpm} / \mathrm{cm}^{2} / \mathrm{y}$ in the study area, Tsunogai et al., 1985), $\lambda_{P b}$ is the decay constant of ${ }^{210} \mathrm{~Pb}\left(0.031 \mathrm{y}^{-1}\right)$, and $\Psi$ is the first-order scavenging rate constant $\left(\mathrm{y}^{-1}\right)$ for $\mathrm{Pb}$. The I's are the inventories (in $\mathrm{dpm} / \mathrm{cm}^{2}$ ) integrated to the penetration depth at which ${ }^{210} \mathrm{~Pb}$ and ${ }^{226} \mathrm{Ra}$ have equal activity. The excess ${ }^{210} \mathrm{~Pb}$ inventory is $\mathrm{I}_{P b}-\mathrm{I}_{R a}$.

Using this equation, the $\Psi$ value for each pair of the inventories within the box can be calculated. The scavenging residence time, $\tau_{\Psi}$, is simply $1 / \Psi$. Both $\Psi$ and $\tau_{\Psi}$ are listed in Table 3 which also summarizes relevant data used for the calculations. The $\tau_{\Psi}$ values range between 2.3 and $8.8 \mathrm{yrs}$. The high value of 8.8 yrs is due to the deep penetration (compared with the T11 ${ }^{226} \mathrm{Ra}$ profile) resulting in a high ${ }^{210} \mathrm{~Pb}$ inventory. The other $\tau_{\Psi}$ values are, in general, still greater than the ${ }^{210} \mathrm{~Pb}$ scavenging residence time of about 1.5 
yrs in the upper $150 \mathrm{~m}$ layer (Lin and Chung, 1991). This difference arises from the greater ${ }^{210} \mathrm{~Pb}$ inventory in the box (in this study $>260 \mathrm{~m}$, see Table 3). Since the excess ${ }^{210} \mathrm{~Pb}$ inventory is quite small, the atmospheric flux, $F$, has a large effect on $\Psi$ or $\tau_{\Psi}$. Increasing $F$ increases $\Psi$, while increasing the ${ }^{210} \mathrm{~Pb}$ inventory, $\mathrm{I}_{P b}$, increases $\tau_{\Psi}$. Since $\mathrm{I}_{P b}$ increases with the integrated depth, the deeper the excess ${ }^{210} \mathrm{~Pb}$ penetrates, the longer the $\tau_{\Psi}$ is. This relation is clearly seen in Table 3 . In the marginal sea where the penetration depth is about $300 \mathrm{~m}, \tau_{\Psi}$ is about 2 to 3 yrs.

\section{SUMMARY AND CONCLUSIONS}

In the area off eastern Taiwan where the Kuroshio flows northward, ${ }^{226} \mathrm{Ra}$ in the surface water appears to increase northward. The surface water ${ }^{226} \mathrm{Ra}$ in the study area varies somewhat randomly between 6.1 and $12.8 \mathrm{dpm} / 100 \mathrm{~kg}$, and no clear correlation with hydrographical data can be recognized (Figure 2). Although the variation (a factor of 2) is much greater than that in the open oceans, it is quite comparable to that observed by Nozaki $(1989)$ in the northern East China Sea and Yellow Sea.

The ${ }^{226} \mathrm{Ra}$ profiles from the shallow stations $(<500 \mathrm{~m})$ in the East China Sea shelf and upper slope areas show a fairly uniform value at about $10 \mathrm{dpm} / 100 \mathrm{~kg}$ (Figure 4A). Those from the intermediate depth $(<1500 \mathrm{~m})$ off the east coast and northeast of Taiwan show a monotonous northward increase from T11 via T14 to T17 and two other stations (14 and C16) below $200 \mathrm{~m}$ (Figure 4B). This trend is consistent with the hydrographic data which indicate that the southern stations (T11, T14) have higher salinity maximum, lower salinity minimum and higher dissolved oxygen associated with lower silicate (above $500 \mathrm{~m}$ ) than the northern stations (T17, 14). The deep ${ }^{226} \mathrm{Ra}$ profiles (T11 and T11') from the deep basin show a gradual increase from $12 \mathrm{dpm} / 100 \mathrm{~kg}$ at $1000 \mathrm{~m}$ to about $30 \mathrm{dpm} / 100 \mathrm{~kg}$ at $2500 \mathrm{~m}$, below which the ${ }^{226} \mathrm{Ra}$ values are nearly constant (Figure $4 \mathrm{C}$ ). The gross features are quite comparable to those observed from most of the profiles in the northwest Pacific (Chung and Craig, 1980).

The property vs. property diagrams clearly indicate that their relationships change between the southern stations (T1 1, T14) and the northern stations (T17, 14) (Figure 5). This is consistent with the ${ }^{226} \mathrm{Ra}$ data which show a northward increase at the mid-depth. The $\mathrm{Si}^{226} \mathrm{Ra}$ relations for these stations are quite different from those for open ocean stations where linear relationships are often observed except for the deep and bottom water (Chung, 1980). T11 in the deep basin has a very low ${ }^{226} \mathrm{Ra}$ content in shallow and intermediate waters but a high ${ }^{226} \mathrm{Ra}$ content in the deep and bottom waters. Clearly, no linear Si- ${ }^{226} \mathrm{Ra}$ relationships can be eatablished for these stations. This suggests that silicate is not a major $\mathrm{Ra}$ carrier in this region.

Both the ${ }^{210} \mathrm{~Pb}$ and ${ }^{226} \mathrm{Ra}$ profiles show a clear change and a general increase in these tracers from south to north along the Kuroshio off the east coast of Taiwan (Figure 7). The northward increase in such a short distance within the Kuroshio appears to be against the conventional notion which would predict no significant change. However, the increase is also accompanied by the hydrographical data which are clearly different between the southern and the northern stations (Figures 3 and 5). Since the decay rate of the excess ${ }^{210} \mathrm{~Pb}$ within the excess layer is small compared to the atmospheric flux, the scavenging rate constant in this layer must be controlled mainly by the atmospheric flux and the total ${ }^{210} \mathrm{~Pb}$ inventory in the layer. The mean residence time of $\mathrm{Pb}$ calculated with respect to particulate scavenging within the excess ${ }^{210} \mathrm{~Pb}$ layer ranges from 2.3 to 8.8 yrs (Table 3). These values are greater 
than those estimated from the mass balance and transfer rate of ${ }^{210} \mathrm{~Pb}$ from the dissolved to the particulate phase in the upper $150 \mathrm{~m}$ layer (Lin and Chung, 1991). Such differences arise from the fact that the layer adopted for these box model calculations $(>260 \mathrm{~m})$ is much thicker than that adopted by Lin and Chung (1991).

Table 3. $\mathrm{Pb}-210$ and Ra-226 inventories $\left(\mathrm{I}_{p b}\right.$ and $\mathrm{I}_{R a}$ ), scavenging residence time $\left(\tau_{\Psi}\right)$, and scavenging rate constant $(\Psi)$ calculated on the basis of a box model for the excess $\mathrm{Pb}-210$ layer.

\begin{tabular}{|c|c|c|c|c|c|c|}
\hline Stn & Pen. Depth ${ }^{*}$ & $\mathrm{I}_{\mathrm{Pb}}$ & $\mathrm{I}_{\mathrm{Ra}}$ & $\mathrm{Pb}-\mathrm{I}_{\mathrm{Ra}}$ & $\Psi$ & $\tau_{\Psi}$ \\
\hline \multicolumn{2}{|r|}{ (m) } & \multicolumn{3}{|c|}{$-\left(\mathrm{dpm} / \mathrm{cm}^{2}\right)$} & $\left(y^{-1}\right)$ & $(y)$ \\
\hline \multirow[t]{2}{*}{ R23 } & $1000 \mathrm{~m}$ & 12.9 & $8.5(\mathrm{~T} 11)$ & 4.4 & 0.113 & 8.8 \\
\hline & $600 \mathrm{~m}$ & 7.8 & $6.0(\mathrm{~T} 14)$ & 1.8 & 0.198 & 5.1 \\
\hline \multirow[t]{2}{*}{ R19 } & $300 \mathrm{~m}$ & 4.0 & $1.9(\mathrm{~T} 14)$ & 2.1 & 0.384 & 2.6 \\
\hline & $260 \mathrm{~m}$ & 3.6 & $2.3(\mathrm{~T} 17)$ & 1.3 & 0.433 & 2.3 \\
\hline H16 & $360 \mathrm{~m}$ & 5.9 & 3.6(T17) & 2.3 & 0.259 & 3.9 \\
\hline 4531 & $300 \mathrm{~m}$ & 4.6 & $2.9(14, \mathrm{C} 16)$ & 1.7 & 0.336 & 3.0 \\
\hline
\end{tabular}

* The penetration depth is taken to be the depth at which the $\mathrm{Pb}-210$ and $\mathrm{Ra}-226$ activities are equal.

Acknowledgments The authors appreciate the sampling opportunity provided by the KEEP-MASS program on the Russian $R / V$ Vinogradov, and the assistance of scientists and crew on board, especially Drs. J. J. Hung and M. P. Chen, who took time and pain to design the casts and collect the samples. Gratitude is also due to the scientists, technicians, and crew on board the $R / V$ Ocean Researcher I during the sampling cruises (\#314, \#338, \#348) for their cooperation and help in sample collections. Thanks are also extended to Ms. L. C. Hung and Mr. C. N. Chen who helped on the word processing and figure preparation. The laboratory measurements as well as the field work were supported by the National Science Council, R.O.C. (NSC 79-0209-M-110-02; NSC 80-0209-M-110-06; NSC 81-0209-M-11004; NSC 82-0209-M-110-043-K).

\section{REFERENCES}

Bacon, M. P., D. W. Spencer, and P. G. Brewer 1976: Pb-210/Ra-226 and Po-210/Pb-210 disequilibria in seawater and suspended particulate matter. Earth Planet. Sci. Lett., 32, 277-296.

Bollinger, M. S., and W. S. Moore 1984: Radium fluxes from a salt marsh. Nature, 309, 444-446.

Broecker, W. S., Y. H. Li, and J. Cromwell 1967: Radium 226 and radon 222 : Concentration in Atlantic and Pacific Oceans. Science, 158, 1307-1310.

Broecker, W. S., J. Goddard, and J. Sarmiento 1976: The distribution of Ra-226 in the Atlantic Ocean. Earth Planet. Sci. Lett., 32, 220-235.

Chern, C. S., and J. Wang 1989: On the water masses at northern offshore area of Taiwan. Acta Oceangr. Taiwanica, 22, 14-32. 
Chen, M. P. and A. Bychkov (Eds.), 1992: ROC-Russia Marine Science Collaboration Project: KEEP-MASS Initial Data Report, Taipei, 450pp.

Chung, Y. 1971: Pacific deep and bottom water studies based on temperature, radium and excess-radon measurements, $\mathrm{Ph}$. D. Thesis, University of California, San Diego, 1-139.

Chung, Y. 1980: Radium-barium-silica correlations and a two-dimensional radium model for the world ocean. Earth Planet. Sci. Lett., 49, 309-318.

Chung, Y. 1981: Pb-210 and Ra-226 distributions in the Circumpolar waters. Earth Planet. Sci. Lett., 55, 205-216.

Chung, Y. 1987: Ra-226 in the western Indian Ocean. Earth Planet. Sci. Lett., 85, 11-27.

Chung, Y. 1987: $\mathrm{Pb}-210$ in the western Indian Ocean: distribution, disequilibrium and partitioning between the dissolved and particulate phases. Earth Planet. Sci. Lett., 85, 28-40.

Chung, Y., and H. Craig 1973:-Radium-226 in the eastern equatorial Pacific. Earth Planet. Sci. Lett., 17, 306-318.

Chung, Y., and H. Craig 1980: Radium-226 in the Pacific Ocean. Earth Planet. Sci. Lett., 49, 267-292.

Chung, Y., and $\mathrm{H}$. Craig 1983: $\mathrm{Pb}-210$ in the Pacific : the GEOSECS measurements of particulate and dissolved concentrations. Earth Planet. Sci. Lett., 65, 406-432.

Craig, H., S. Krishnaswami, and B. L. K. Somayajulu 1973: Pb-210-Ra-226: radioactive disequilibrium in the deep sea. Earth Planet. Sci. Lett., 17, 295-305.

Elsinger, R. J., and W. S. Moore 1980: Ra-226 behavior in the Pee Dee River-Winyah Bay Estuary. Earth Planet. Sci. Lett., 48, 239-249.

Elsinger, R. J., and W. S. Moore 1983: Ra-224, Ra-228, Ra-226 in the Winyah Bay and Delaware Bay. Earth Planet. Sci. Lett., 48, 239-249.

Elsinger, R. J., and W. S. Moore 1984: Ra-226 and Ra-228 in the mixing zones of the Pee Dee River-Winyah Bay, Yangtze River and Delaware Bay estuaries. Estuar. Coast. Shelf Sci., 18, 601-613.

Fan, K. L. 1980: On upwelling off northeastern shore of Taiwan. Acta Oceanogr. Taiwanica, 11, 105-117.

Fanning, K. A., J. A. Breland (II), and R. H. Byrne 1982: Radium-226 and radon-222 in the coastal waters of west Florida: high concentrations and atmospheric degassing. Science, 215, 667-670.

Harada, K., and S. Tsunogai 1986: Ra-226 in the Japan Sea and the residence time of Japan Sea water. Earth Planet. Sci. Lett., 77, 236-244.

Koczy, F. F. 1958: Natural radium as a tracer in the ocean, Proc. Second U. S. Int. Conf. Peaceful Uses of Atomic Energy, 18, 351-357.

Ku, T. L., Y. H. Li, G. G. Mathieu, and H. K. Wong 1970: Radium in the Indian-Antarctic Ocean south of Australia. J. Geophys. Res., 75, 5286-5292.

Ku, T. L., and M. C. Lin 1976: ${ }^{226}$ Ra distribution in the Antarctic Ocean. Earth Planet. Sci. Lett., 32, 236-248. 
Ku, T. L., C. A. Huh, and P. S. Chen 1980: Meridional distribution of ${ }^{226} \mathrm{Ra}$ in the eastern Pacific along GEOSECS cruise tracks. Earth Planet. Sci. Lett., 49, 293-308.

$\mathrm{Ku}, \mathrm{T}$. L., and S. Luo 1994: New appraisal of radium 226 as a large-scale oceanic mixing tracer. J. Geophys. Res., 99, 10255-10273.

Lin, Y. N., and Y. Chung 1991: ${ }^{210} \mathrm{~Pb}$ and ${ }^{210} \mathrm{Po}$ distributions and their radioactive disequilibria in the Kuroshio waters off eastern and northeastern Taiwan. TAO, 2, 243-265.

Liu, C. T. 1983: As the Kuroshio turns, II: Characteristics of the current. Acta Oceanogr. Taiwanica, 14, 88-95.

Liu, C. T., and S. C. Pai 1987: As the Kuroshio turns, II: The oceanic front north of Taiwan. Acta Oceanogr. Taiwanica, 18, 49-61.

Liu, K. K., G. C. Gong, C. Z. Shyu, S. C. Pai, C. L. Wei, and S. Y. Chao 1992: Response of Kuroshio upwelling to the onset of the northeast monsoon in the sea north of Taiwan: Observations and a numerical simulation. J. Geophys. Res., 97, 12511-12526.

Moore, W. S. 1981: Radium isotopes in Chesapeake Bay. Estuar. Coast. Shelf Sci., 21, 713-723.

Nitani, H. 1972: Beginning of the Kuroshio, In: H. Stommel and Y. Yoshida (Eds)., KuroshioIts Physical Aspects, University of Washington Press, Seattle, Wash., 129-163.

Nozaki, Y. 1989: Mean residence time of the shelf water in the East China and Yellow Seas determined by Ra-228/Ra-226 measurements. Geophys. Res. Lett., 16, 1297-1300.

Tsunogai, S., T. Shinagawa, and T. Kurata 1985: Deposition of anthropogenic sulfate and $\mathrm{Pb}-210$ on the western north Pacific area. Geochem. J., 19, 77-90.

Wong, G. T. F., S. C. Pai, K. K. Liu, C. T. Liu, and C. T. A. Chen 1991: Variabilitty of the chemical hydrography at the frontal region between the East China Sea and Kuroshio north-east of Taiwan. Estuar. Coast. Shelf Sci., 33, 105-120.

Yang, C. Y., and H. C. Lin 1992: Lead-210 and polonium-210 across the frontal region between the Kuroshio and the East China Sea, northeast of Taiwan. TAO, 3, 379-394. 
